\title{
ENVIRONMENTAL EFFECTS OF IRRIGATION IN ARID AND SEMI-ARID REGIONS
}

\author{
Alicia Fernández-Cirelli', José Luis Arumí2, Diego Rivera² ${ }^{2}$ and Peter W. Boochs ${ }^{3}$
}

\begin{abstract}
This article reviews the state of the art with respect to the environmental effects of irrigated agriculture on water and soil quality in arid and semi-arid regions on a field scale. Information is scarce and fragmentary. Examples in selected areas of other arid and semi-arid regions in the world clearly show the importance of studying the environmental impact of irrigation practices on water and soil quality. Studies mainly refer to waterlogging and salinization. As regards agrochemicals, fertilizers have been taken into account through nitrate leaching. The impact of micropollutants such as pesticides and heavy metals on water and soil quality is studied mainly by modeling. Pharmaceutical compounds emerge as pollutants when wastewater is used for irrigation without any previous treatment, situation which is now the object of new studies. There is an obvious need to study in-depth knowledge related to appropriate technologies for the use, treatment, and reuse of wastewater which is a valuable resource in arid and semi-arid regions.
\end{abstract}

Key words: irrigation, water quality, soil quality, agrochemicals, micropollutants.

\section{INTRODUCTION}

High demographic growth and rapid development of economic activity have resulted in an agricultural intensification process to increase food production. Only $20 \%$ of the world's croplands are irrigated, but they produce $40 \%$ of the global harvest meaning that irrigation more than doubles land productivity. In arid and semi-arid regions, irrigation improves economic returns and can boost production by up to $400 \%$. On the other hand, irrigation can produce unwanted environmental consequences. About one-third of the world's irrigated lands have reduced productivity as a consequence of poorly managed irrigation that has caused waterlogging and salinization.

Given current demographic trends and future growth projections, as much as $60 \%$ of the global population may suffer water scarcity by the year 2025 (Qadir et

${ }^{1}$ Universidad de Buenos Aires, Facultad de Ciencias Veterinarias, Centro de Estudios Transdisciplinarios del Agua, Av. Chorroarin 280, Ciudad Autónoma de Buenos Aires, Argentina

(afcirelli@fvet.uba.ar).

${ }^{2}$ Universidad de Concepción, Facultad de Ingeniería Agrícola, Departamento de Recursos Hídricos, Av. Vicente Méndez 595, Chillán, Chile (jarumi@udec.cl).

${ }^{3}$ Leibniz Universität Hannover, Institute of Water Resources Management, Hydrology and Agricultural Hydraulic Engineering (WAWI), Appelstr. 9A, 30167 Hannover, Germany

(boochs@iww.uni-hannover.de). al., 2007). Water use efficiency techniques applied with conventional resources have been improved. However, water-scarce countries will have to rely more on the use of non-conventional water resources to partly alleviate water scarcity. Non-conventional water resources are either generated as a product of specialized processes such as desalination, or need suitable pre-use treatment and/or appropriate soil-water-crop management strategies when used for irrigation. In water-scarce environments, such water resources are accessed through the desalination of seawater and highly brackish groundwater, harvesting of rainwater, and use of marginal-quality water resources for irrigation. Marginal-quality irrigation waters consist of wastewater, agricultural drainage water, and groundwater containing different types of salts. A major part of the wastewater generated by domestic, commercial, and industrial sectors is used for crop production in an untreated or partly treated form in many developing countries. Protection of public health and the environment are the main concerns associated with uncontrolled wastewater irrigation. The use of saline and/ or sodic drainage water and groundwater for agriculture is expected to increase. This warrants modifications in the existing soil, irrigation, and crop management practices in order to cope with the increases in salinity and sodicity that will occur.

Some of the challenges faced by present-day irrigated agriculture are summarized as follows: 1) More efficient 
use of inputs (water, fertilizer, pesticides, and labor) aimed at reducing negative impacts on the environment and production costs; 2) Soil salinity, matching landscape capability with irrigation systems when deciding on new locations for irrigation development or on-farm field suitability; 3) Minimizing environmental impacts by quantifying both positive and negative externalities of different irrigation areas and sectors, and by evaluation, auditing, and benchmarking in the irrigation industry. Management of negative environmental impacts, such as methane and nitrous oxide emission, salinity, water pollution (abuse of pesticides), algal blooms, etc., especially in intensive crop production systems; 4) Balancing irrigation and environmental flow demands through real savings due to improved distribution and on-farm water use efficiency and alternative cropping options; 5) Maintaining and enhancing drainage water quality, and minimizing impacts on rivers and ecosystems; 6) Institutional robustness in terms of the failure of the institution and ecosystem through better definition of property rights (FAO, 2000; World Bank, 2007).

While some climate and management aspects are common to semi-arid regions, detailed mechanisms and options to secure ecological sustainability and economic viability may vary considerably from case to case (Khan et al., 2006).

The introduction of irrigation in arid and semi-arid environments inevitably leads to water table variations, and often to problems of waterlogging and salinization. Nitrate resulting from nitrogen fertilizers used in agriculture is a widespread contaminant of groundwater and causes adverse effects on the health of humans, animals, and the ecosystem. Nitrates are not the only pollutants attributable to irrigation, so are plant nutrients in general, pesticides, and heavy metals. Pharmaceutical compounds emerge as pollutants when wastewater is used for irrigation without any previous treatment (Siemens et al., 2008).

This article reviews the state of the art with respect to the environmental effects of irrigated agriculture on water and soil quality in arid and semi-arid regions in Latin America on a field scale. Examples in selected areas of other arid and semi-arid regions in the world, as well as modeling and case studies are presented.

\section{WATER AND SOIL QUALITY IN ARID AND SEMI-ARID REGIONS IN LATIN AMERICA}

The factors underlying irrigation development in Latin America and the Caribbean have been examined in a report prepared by the Inter-American Development Bank (2000) reviewing the water supply situation, as well as describing trends in water demand and irrigated agriculture. This article concludes that, in this context of accelerating demand and declining irrigation investments, greater attention is needed for water policy and management reform in order to improve the efficiency and equity of irrigation and water supply systems. Contaminated wastewaters are frequently used for irrigation. Improper agricultural water use in Latin America results in salinization, waterlogging, eroding agricultural lands, and polluting water for agricultural use. There is also a high risk of desertification in about $20 \%$ of the total area of South America (Argentina 60\%, Chile $45 \%$, Bolivia 25\%, and Peru 20\%).

A description of the water use and irrigation situation in Latin America and the Caribbean countries, with a focus on large-scale irrigation systems, has been reported by FAO (2000). In 1993, FAO began developing the double purpose AQUASTAT program, which is an information system on water use for rural development and agriculture: a) to provide a clear picture of the situation of rural water resources management on a country basis with emphasis on irrigation, and featuring major characteristics, trends, constraints, and perspectives; and b) to help support continental and regional analyses by providing systematic, up-to-date, reliable information on water for rural development and agriculture, and serve as a tool for large-scale planning and forecasting.

The World Bank (2007) recently presented a report on empirical agricultural models of the choice of irrigation to examine how they are influenced by climate. The article models the choice of whether to grow crops, own livestock, or install irrigation, and also tests whether they are influenced by temperature and precipitation.

With regard to reports of individual countries in the region, a description of the legal framework has been prepared for water resources management in Argentina, and the regulatory gap as regards pollution and water quality at the national level (World Bank, 2000). Analysis focuses on aquifer systems in the provinces of Mendoza, Buenos Aires, and Santa Fe as being representative of the country's overall groundwater resources. There has been a rapid expansion in complementary irrigation in the agricultural sector using the easily accessible Puelches and Pampeano (Pampean region) aquifers. Water quality problems have been reported in the provinces of Córdoba, Catamarca, Tucumán, and Mendoza.

Vázquez et al. (2006) carried out research on the sustainability of irrigated production systems at northwest/mideast sites in the Province of Buenos Aires. Furthermore, some results are found on the degradation of semi-arid rangelands in the Argentinean Pampa due to increasing grazing intensity (Noellemeyer et al., 2006), susceptibility to dispersion, effect on the soil water retention, and hydraulic properties of two irrigated soils, 
Typic Udipsament and Entic Hapludol, respectively, in the center-east and northwest of the Province of Buenos Aires, Argentina.

Groundwater contamination by nitrogen compounds was studied in a rural area in the southeast of the Province of Buenos Aires. Results showed that high fertilization rates and irrigation led to increased hazards of groundwater pollution (Costa et al., 2002). Two soils were treated with artificial irrigation waters with different sodium adsorption ratios (SAR), with the object of finding predictive models. The models found permit to diagnose sodicity and $\mathrm{pH}$ the studied soils acquire when subjected to the irrigation water with different levels of SAR (Ruda et al., 2005).

In arid environments, dry and wet years have a similar number of small rainfall events, but wet years result with the occurrence of a few large rainfall events. The differential response of soil processes to wet and dry years has been analyzed. Litter decomposition and soil $\mathrm{N}$ mineralization responses to excess precipitation in the Patagonian steppe were compared with responses to drought conditions previously reported for this ecosystem. Reported results suggest that the different microorganisms responsible for nitrification and ammonification have differential sensitivity to water availability, and that environmental controls might be overwhelmed by substrate availability on longer time scales (Yahdjian and Sala, 2008).

Applying high rates of nitrogen $(\mathrm{N})$ fertilizer to crops has two major disadvantages: low $\mathrm{N}$ fertilizer use efficiency, and loss of $\mathrm{N}$ by leaching which may cause groundwater nitrate pollution, especially in humid areas. A study was carried out in humid Argentina to adjust and validate the Leach-W model (Leaching Estimation and Chemistry Model) with data observed in the field. This deterministic model has proven to be useful in quantifying nitrate concentrations in the soil solution, estimating $\mathrm{N}$ loss by leaching, and determining the moments during the year when the greatest nitrate transport events occur beyond the rooting profile. Results suggested that nitrate-nitrogen losses increased as the rate of applied $\mathrm{N}$ increased. The greatest nitrate-nitrogen losses through leaching occurred during crop growth (Aparicio et al., 2008).

Irrigation waters with high sodicity and low salinity levels can deteriorate soil physical properties, and consequently affect water movement in the soil. A study was carried out to evaluate the effect of supplemental irrigation with water having residual sodium carbonate (RSC) greater than $1.25 \mathrm{mmol} \mathrm{L}^{-1}$ on hydraulic conductivity (K) of Hapludolls and Argiudolls located in the State of Santa Fe, Argentina, as well as to identify the possible causes of $\mathrm{K}$ alteration. Irrigated and non-irrigated plots were selected to evaluate soil bulk density, water dispersed clay content, and $\mathrm{K}$ in two depth intervals.
Results emphasize the importance of preventing soil dispersion (Ghiberto et al., 2007).

In Brazil, several studies were performed which included the use of wastewater. A pilot field study was conducted to determine the chemical effects on the soilplant system of secondary treated wastewater from the city of Lins (State of São Paulo, Brazil) used to irrigate a coffee (Coffea arabica L.) plantation (Herpin et al., 2007). Furthermore, an evaluation of the effect of soil temperature on the potential of herbicide leaching into groundwater in the Brazilian Cerrado was reported (Costa Paraíba et al., 2003). There are studies that try to elucidate pesticide transport in an Oxisol under preferential flow conditions (Reichenberger et al., 2002) and evaluate the variation in soil solution chemistry during the irrigation of maize (Zea mays) and sunflower (Helianthus annuus) crops with sewage effluent in a Brazilian Oxisol (Herpin et al., 2007). A greenhouse experiment was carried out to show the dependence of wetting-drying cycles (WDC) on the mineralogical composition of Oxisols (Latosols). Results led to the conclusion that soils with reduced aggregate stability are more susceptible to the action of wetting and drying on the WDC (Senna de Oliveira et al., 2005). Recent changes in crop and animal production systems in Brazil were evaluated in the context of probable implications of the fate of $\mathrm{P}$ in agriculture (Shigaki and Prochnow, 2006).

Long-term soil management experiments (10 and 15 years) were conducted to evaluate the effectiveness of the Soil Quality Kit (SQK) by comparing them to traditional soil science methods. SQK was an efficient tool to evaluate soil quality and the highest levels were achieved under no-tillage with a tropical-grass legume consortium, which provides soil cover, high carbon, and nitrogen addition through crop residues (Amado et al., 2007).

Secondary treated wastewater (STW) from an anaerobic/facultative pond system in the city of Lins (Sao Paulo State, Brazil) was used over 3 years and 7 months to irrigate coffee. Soil type was Typic Haplustox and the crops were fertilized according to regional agronomic recommendations. Soil and leaf samples from three sampling campaigns were used to study the effects on chemical quality parameters, macronutrients, and Na within the soil-plant system (Herpin et al., 2007). Stream water flows and in-stream nitrate and ammonium concentrations were simulated in a small catchment using the Integrated Nitrogen in Catchment Model (OjedaBustamante et al., 2007). In this catchment, intensive farming and growing pressures toward urbanization are observed. Attempts were made to characterize the different uses and physical-chemical quality of groundwater in part of the semi-arid area of Piauí, in view of using it for irrigation (Andrade et al., 2006). Studies were carried 
out to evaluate the quality of the water used to irrigate rice (Oryza sativa) by considering different plant growth periods.. The dissipation and leaching characteristics of pesticides in tropical soil (Costa Paraíba et al., 2003) and the potential for non-point groundwater pollution were studied (Reichenberger et al., 2002).

Senna de Oliveira et al. (2005) reported the usefulness of dissolved organic carbon and bioavailability of $\mathrm{N}$ and $\mathrm{P}$ as indicators of soil quality in Brazilian soils. They attempted to provide an in-depth analysis about the relationship between water scarcity, irrigated agriculture, and the environment, while contributing at the same time to studies that may lead to planned agriculture, preserving, and optimizing natural resources.

A study has been reported dealing with the effects of intermittent irrigation on actual evapotranspiration (ET) and leaf area index (LAI) of grapevines (Vitis vinifera L.) grown in a semi-arid environment in northeastern Brazil (Vieira de Azevedo et al., 2008). ET increased when the irrigation interval increased resulting in a higher value of LAI. Integrated studies including climatology, hydrology, and socio-economic aspects are required both for analyzing the dynamic natural conditions and assessing possible strategies to make semi-arid regions less vulnerable. A model was introduced that dynamically describes the relationships between water availability, agriculture, and selected societal processes. It has been tailored to simulate the rather complex situation in semi-arid northeastern Brazil in a quantitative way including sensitivity to external forces such as climate change. Simulation results show that, independently of differences in climate change scenarios, rainfed farming is more vulnerable to drought impacts than irrigated farming. However, irrigation capacity and other water infrastructure systems to enhance resilience with respect to climatic fluctuations are significantly constrained given an important negative precipitation trend (Maarten et al., 2006).

In Mexico, there are reports on different environmental effects of irrigated agriculture. Gallegos et al. (1999) developed research to determine the impact of wastewater irrigation on groundwater at two locations (Leon and Mezquital Valley), finding higher levels of coliforms and nitrate concentration. Herre et al. (2004) studied the long-term effect of untreated wastewater irrigation which was evaluated in a district where it has been used since 1912. Accumulated heavy metals are bound mainly to the organic soil fraction. Results showed an increase of dissolved organic carbon and bioavailable $\mathrm{Cu}$ and $\mathrm{Cd}$. The Collembola community from two agroecosystems with contrasting irrigation types were compared in the State of Hidalgo (Cutz-Pool et al., 2007) stating that soil properties such as $\mathrm{pH}$, electrical conductivity (EC), organic matter (OM), and exchangeable contents of cations $\left(\mathrm{Mg}^{2+}, \mathrm{Na}^{+}\right)$appear to affect the composition and abundance of these communities. A computer tool allowing the dynamic generation of digital map reports was developed and transferred to water user associations (WUA) of irrigation districts (Ojeda-Bustamante et al. 2007).

Effluents from leather processing, a major industry in the town of León, Mexico, are normally discharged to the Turbio River without treatment and used downstream to irrigate agricultural land. Tannery wastewater contains valuable nutrients, but also contaminants such as salts and chromium $(\mathrm{Cr})$ that could affect soil processes and crop production. It has been reported how almost 25 years of irrigation of agricultural land with water from the Turbio River has affected the dynamics of carbon and nitrogen, as well as the production of nitrous oxide under different water regimes and fertilizer application rates. It was found that respiration and nitrification were not affected by this irrigation water, but nitrous oxide production was greater in soil irrigated with water from the Turbio River than in soil irrigated with well water (Trujillo-Tapia et al., 2008).

Concentrations and retention of pharmaceutically active substances are crucial to assess the environmental risk of medication on humans. Environmental introduction concentrations (EICs) of drugs in the Mexico City-Mezquital Valley wastewater irrigation system was estimated by using information about water consumption, sales data, and excretion rates. Calculated EICs of all compounds except metoprolol and clarithromycin were comparable to measured concentrations when excretion rates were considered. Whereas concentrations of basic compounds with positive or neutral charges were effectively reduced during reservoir storage and soil passage, acidic anionic compounds were hardly retained. Though realistic EICs can be predicted for most substances, large deviations between EICs and measured concentrations in the case of metoprolol illustrate that estimated concentrations cannot substitute monitoring programs (Siemens et al., 2008).

Groundwater from the Costa de Hermosillo aquifer has been used extensively for irrigation over the past 60 years in the Sonora region of northwestern Mexico resulting in salinization of fresh groundwater resources. Isotopic composition of present-day surface discharge from agricultural fields is substantially enriched in ${ }^{32} \mathrm{~S}$ due to widespread application of ammonium sulphate fertilizers and $\mathrm{S}$ mobilization potential of mineral resources (Szynkiewicz et al., 2008).

The area irrigated with sewage water in the Mezquital Valley in central Mexico has steadily expanded during the last 100 years providing the opportunity to assess the effects of this practice, particularly on mycorrhizae. 
Concentrations of zinc, lead, copper, and cadmium appeared to have increased linearly over time, while mycorrhizae diversity decreased in the long-term (OrtegaLarrocea et al., 2007).

In Bolivia, the application of deficit irrigation (DI) to stabilize yield and to increase water productivity of quinoa (Chenopodium quinoa Willd.) raises questions in the arid southern Altiplano where water resources are limited and often saline. Rainfed quinoa and quinoa with irrigation restricted to flowering and early grain filling were studied during the 2005-2006 and 2006-2007 growing seasons. Results showed that irrigation of quinoa with saline water and/or capillary rise from a saline shallow water table could result in significant salt accumulation in the root zone after just 1 year (Geerts et al., 2008)

In Chile, effects were reported of agricultural activities on water pollution. A sensitivity analysis and a preliminary short-term, site-scale performance assessment of analytical soil and groundwater nitrate transport were carried out (Oyarzun et al., 2007). Both the nitrate flux from the vadose zone and nitrate groundwater concentration are mainly influenced by the initial soil nitrogen levels, water input, and soil porosity. Intensive farming areas in southern Chile showed nitrate levels that were higher in deep wells than in extensive farming areas (González et al., 2004). Diffuse nitrogen pollution caused by irrigated agriculture has been quantified for the Pocochay stream located in the Aconcagua watershed in the Valparaíso Region. The study area under irrigation extends $93 \times 36 \mathrm{~km}^{2}$. It is representative of the central part of Chile where intensive irrigation prevails and predominantly takes place in the alluvial plains of river systems with water sources from the Andes Mountains. Even though nitrate concentrations in the Pocochay have not yet reached alarming levels, the impact of irrigated agriculture on surface water quality is evident and makes a case for introducing better management practices to avoid aggravation of contamination (Ribbe et al., 2008).

In Uruguay, a case study was reported about vegetable farms and the influence of farm resource endowment on the possibilities of sustainable development (Dogliotti et al., 2006). Mantel et al. (2000) presented a methodology that explores soil survey information at the national level, thus generating sustainability indicators for wheat cultivation. The fertility capability soil classification system (FCC) was applied to analyze soil quality in the tropics. It is based on quantitative topsoil attributes and soil taxonomy and does not deal with soil attributes that can change in less than one year, but rather with those that are either dynamic on time scales of years or decades with management, as well as inherent ones that do not change in less than a century. FCC attributes can be positive or negative depending on land use, as well as the temporal and spatial scales for the case in question (Barrios et al., 2006).

The effects of field compaction of different soilwater statuses on pore size distribution and soil water characteristics of a Rhodic Ferralsol were studied in western Cuba. The use of field capacity water content as the upper limit of plant available soil water was considered inappropriate for compacted soils (Tarawally et al., 2004). Peasant agriculture and soil awareness were examined in the Central mountain chain of the Dominican Republic (Ryder, 2003). This study demonstrated that empirical knowledge of site suitability is of great value to verify scientific site suitability ratings derived from parametric indices, thus strengthening the fact that the participatory approach to agricultural research and development is particularly relevant in soil survey. In another study, similarities and differences were explored between the views on soil quality issues of farmers and scientists in central Honduras (Ericksen et al., 2003). The authors investigated ways in which local farmers categorized and managed soils and land uses. Farmer understanding of soil quality was heavily influenced by the fact that agricultural production was their primary concern, whereas soil scientists have a more holistic view of plant productivity. Nitrate sorption potential was compared in two coffee plantations in Costa Rica. Nitrate occupied less than $10 \%$ of the total anion adsorption capacity, suggesting that adsorption can have a long-term potential for mitigation or delay of nitrate leaching (Ryan et al., 2001).

A participatory approach and a methodological guide were developed to identify and classify local indicators of soil quality, relating them to technical soil parameters, thus developing a common language between farmers, extension workers, and scientists. This methodological guide was initially developed and used in Latin America and the Caribbean (Honduras, Nicaragua, Colombia, Peru, Venezuela, and the Dominican Republic) and was later improved by adapting and using it in Eastern Africa (Uganda, Tanzania, Kenya, and Ethiopia) during a SouthSouth exchange of expertise and experiences (Barrios et al., 2006).

\section{WATER AND SOIL QUALITY IN SELECTED ARID AND SEMI-ARID REGIONS IN THE WORLD}

The technology of irrigated agriculture has often been controversial. Development agencies would praise its productivity since $40 \%$ of the world's human food supply is produced by only $20 \%$ of the world's irrigated cultivated land. Environmental and ecological concerns cite the degradation of natural landscapes, elimination of floodplains and wetlands, as well as profound impacts 
on wildlife habitats. Fiege (1999) proposes in his book that irrigation should be viewed as a man-made ecological system in which land and water are modified to increase agricultural production. Oad and Kullman (2006) have used this ecological approach to study the Middle Rio Grande (USA), landscape irrigated with the purpose of identifying options for water and ecosystem conservation. This report presents research findings related to opportunities in the agricultural sector to reduce water diversions from the river, primarily by changing the practice of continuous canal water delivery to rotational water delivery. More water is now available in the river for better ecology in general and better fish and wildlife habitat in particular.

González Vázquez et al. (2005) reported that inappropriate farming techniques and four years of drought (1992-1995) produced high nitrate concentration conditions in an aquifer located in the Province of Seville, southwest Spain. The study showed the impact of crops and the cropping system on groundwater quality. Compared to other crops, cotton (Gossypium herbaceum L.) and potato (Solanum tuberosum L.) made the greatest contribution to nitrate pollution and salinization. Alternative farming techniques for these crops, such as monitored fractional fertilization and controlled irrigation are recommended.

Based on a field study on the semi-arid Loess Plateau in China, Li et al. (2004a) studied the strategies of limited farmland irrigation in the dry period of normal precipitation years, and examined the effects on water use and grain yield of spring wheat with dry period irrigation and fertilizer application at sowing. Results indicated that dry period irrigation resulted in larger and deeper root systems and a larger leaf area index than in non-irrigated treatments. The root/shoot ratio in the irrigated treatments was significantly higher than in non-irrigated treatments. Grain yields and water use efficiencies were the highest with dry period irrigation plus fertilizer application.

Effects of water table and fertilization management on nitrogen loading to groundwater were examined by Guo et al. (2006). A field experiment was conducted in an intensively irrigated agricultural area in the Dianchi catchment of Kunming, China in two celery (Apium graveolens) crop sites with different water table depths ( $2.0 \mathrm{~m}$ and $0.5 \mathrm{~m}$ below the soil surface). Fertilizers were applied at both sites at two different rates, the first being the higher rate traditionally used by farmers in the region (about $4800 \mathrm{~kg} \mathrm{~N} \mathrm{ha}^{-1} \mathrm{yr}^{-1}$ ) and the other being one third of this quantity. Results showed that fertilization practices had little impact on water balance and dynamics in the plant-soil-aeration zone-saturated zone system. However, the groundwater table controlled vertical infiltration recharge and evaporation-transpiration rate. Nitrate concentrations of soil water near the groundwater table with the high fertilization rate were greater than with low fertilization. The high fertilization rate consequently resulted in greater nitrogen (including nitrate, nitrite, and ammonium) loadings from the aeration zone to the groundwater. Nitrate was the dominant nitrogen component entering groundwater. Little ammonium and less nitrite were transported in groundwater. The shallow water table made nitrate entering groundwater easier and consequently determined the $\mathrm{NO}_{3}$ loading from the vadose zone.

Zhang et al. (2004) investigated the spatial and temporal variations of water quality in drainage ditches in vegetable farms and citrus groves in St. Lucie County, Florida, USA. Concentrations of nitrogen, phosphorus, and heavy metals were measured. The concentrations ranged from non detectable to $9.13 \mathrm{mg} \mathrm{L}^{-1}$ for $\mathrm{NH}_{4}-\mathrm{N}$, $283 \mathrm{mg} \mathrm{L}^{-1}$ for $\mathrm{NO}_{3}-\mathrm{N}$, and $4.86 \mathrm{mg} \mathrm{L}^{-1}$ for total $\mathrm{P}$. Concentrations of $\mathrm{Cu}$ and $\mathrm{Zn}$ ranged from non detectable to 63.7 and $121.7 \mathrm{~g} \mathrm{~L}^{-1}$, respectively. Spatial and temporal variations of water quality were noted among the different drainage ditches. Since fertilizer rates were higher on the vegetable farms than in the citrus groves, concentrations of $\mathrm{N}, \mathrm{P}$, and $\mathrm{K}$ were generally higher in the ditches on the vegetable farms than in the citrus groves. Seasonally, the higher concentrations of $\mathrm{N}, \mathrm{P}, \mathrm{K}, \mathrm{Cu}$, and $\mathrm{Zn}$ occurred in the wet season rather than in the dry season, which could be as consequence of a higher nutrient input from the adjacent field. Mean $\mathrm{N}, \mathrm{P}, \mathrm{Zn}$, and $\mathrm{Cu}$ concentrations in ditch water were significantly correlated with soil $\mathrm{N}, \mathrm{P}$, $\mathrm{Zn}$, and $\mathrm{Cu}$ levels and annual amounts of $\mathrm{N}$ and $\mathrm{P}$ applied in the adjacent fields. However, concentrations of $\mathrm{Cd}, \mathrm{Co}$, $\mathrm{Cr}, \mathrm{Ni}, \mathrm{Pb}, \mathrm{Mo}$, and As were generally low, with small seasonal variations probably due to limited water-soluble $\mathrm{Cd}, \mathrm{Co}, \mathrm{Cr}, \mathrm{Ni}, \mathrm{Pb}, \mathrm{Mo}$, and $\mathrm{As}$ in the soil of adjacent fields. Results indicated that nutrients and heavy metals accumulated in the soils, and fertilization practices having a significant influence on water quality in adjacent drainage ditches, and water quality of drainage ditch can vary seasonally.

Intensive irrigation can produce high groundwater tables and cause salinity problems. For example, such problems have been reported for the Jezre'el Valley, Israel. A number of drainage system designs were installed in the same field to manage the prevailing causes of salinity hazards. The shallow drainage system was designed to prevent damage to the winter crops and especially enable early seeding of summer crops. The deep drainage system was designed to maintain a relatively low water table, thereby avoiding concentration of salts in the root zone. The combined drainage system with relief wells was designed to relieve upward hydraulic pressure exerted by the semi-confined shallow aquifer. Benyamini et al. (2005) examined the systems. The most efficient drainage 
method was found to be a combination of shallow and deep drains with relief wells wherever the semi-confined shallow aquifer was present. A noticeable improvement in soil salinity, to below $4 \mathrm{dS} \mathrm{m}^{-1}$, was observed 2-3 years after the drainage system was installed. It was found that the water table should be more than $1 \mathrm{~m}$ below the soil surface in the spring season in order to prevent soil salinization.

Hornbuckle et al. (2007) described a multi-level drainage system designed to improve drainage water quality. Results are presented from a field scale land reclamation experimentimplemented in the Murrumbidgee Irrigation Area in New South Wales, Australia. A traditional single-level drainage system and a multi-level drainage system were compared in the experiment carried out in an irrigated field setting. Data on drainage flows and salinity, water table regime, and soil salinity were collected over a 2-year period. The multi-level drainage system provided greater waterlogging protection than the single-level system, and faster leaching of the root zone without increasing drainage salt loads. On the other hand, shallow drains were found to have significantly lower drainage water salinities than deep drains, and the combination of deep and shallow drains in a multi-level drainage system provides significant benefits in relation to drainage water disposal management options when compared to single-level systems.

In a study by Ayars et al. (2006), traditional subsurface drainage system design procedures were described, followed by alternative design criteria for arid regions, and suggestions that system design include control structures enabling better drain system management. Suggested changes included reducing installation depth of laterals, accounting for crop water use from shallow ground water in the design, and relaxing the mid-point water depth requirement. Active control of drainage systems in arid irrigated regions is a developing concept that is currently being evaluated around the world. Research in the USA and Australia has demonstrated that water tables in irrigated areas can be effectively controlled with various types of structures. Control has resulted in reduced volumes of drainage water and total discharged salt loads. Salt accumulation in the root zone is to be considered when adopting controlled drainage, but other research has demonstrated that it is possible to manage salt accumulation through careful water management.

Irrigation development in an arid zone almost always has to deal not only with secondary salinity, but also with primary and fossil salinity. In many cases, irrigation development brings about large-scale changes in the local geohydrological regime which often results in mobilization of salts stored in the underlying substrata. This primary and fossil salt mobilization has been found to be one of the principal causes of river salinization in irrigated basins in the arid zone. The study by Smedema and Shiati (2002) highlights this salinity hazard, which is as yet insufficiently recognized, and discusses related control measures and strategies.

Chowdary et al. (2005) presents the development and application of a geographical information system (GIS)based decision support framework that integrates field scale models of these processes to assess non-point-source pollution of groundwater in canal irrigation project areas. GIS is used to represent spatial variations in input data over the area and to map the output of the recharge and nitrogen balance models. The latter are used to provide the spatially distributed recharge and pollutant load inputs to the distributed groundwater flow and transport models, respectively. Alternate strategies for water and fertilizer use can be evaluated using this framework to ensure long-term sustainability of productive agriculture in large irrigation projects. Development and application of the framework is illustrated by a case study of a large canal irrigation system in India.

Use of reclaimed wastewater (treated wastewater or reused drainage water) for irrigation is an important route for the introduction of pharmaceutical compounds (PCs) into the environment. The mobility and sorptiondesorption behavior of carbamazepine, naproxen, and diclofenac were studied in soil layers sampled from a plot irrigated with secondary treated wastewater (STW). Carbamazepine and diclofenac were significantly retarded in the $0-5 \mathrm{~cm}$ soil sample rich in soil organic matter (SOM); carbamazepine was not affected by water quality (freshwater versus STW), whereas diclofenac exhibited a higher retardation factor (RF) in the freshwater system. Naproxen exhibited significantly lower RFs than diclofenac, but with a similar trend, showed higher retardation in the freshwater system than in the STW system. In the $5-15 \mathrm{~cm}$ soil sample containing low SOM, naproxen was highly mobile while carbamazepine and diclofenac were still retarded. In the $15-25 \mathrm{~cm}$ sample, all compounds exhibited their lowest RFs. Sorption data suggested that SOM governs the studied PC interactions with the soil samples. However, higher carbon normalized sorption coefficients were measured for the PCs in the $15-25 \mathrm{~cm}$ sample, suggesting both quantity and physicochemical nature of SOM affect sorption interactions. While both naproxen and carbamazepine exhibited reversible sorption isotherms, diclofenac exhibited pronounced sorption-desorption hysteresis. This study suggests that carbamazepine and diclofenac can be classified as slow-mobile compounds in SOM-rich soil layers. When these compounds pass this layer and/or are introduced into SOM-poor soils, their mobility increases significantly. This emphasizes the potential transport of 
PCs to groundwater in semi-arid zones due to intensive irrigation with reclaimed wastewater in SOM-poor soils (Chefetz et al., 2008).

In order to evaluate the full extent of groundwater nitrate contamination, and how it might evolve over time, it is essential to understand controls on aquifer assimilative capacity (Arumi et al., 2005). This level of understanding will also help to better target policies and incentives aimed at controlling the amount of nitrate entering downstream water systems. The potential for nitrate attenuation in groundwater was assessed by examining the concentration and distribution pattern of electron donors such as dissolved organic carbon (DOC), ferrous iron, and redox indicators such as dissolved oxygen (DO) and redox potential (Eh) in 57 monitoring bores on the lower Burdekin coastal floodplain, one of Queensland's and Australia's premier irrigation districts. Low nitrate concentrations were coupled with high ferrous concentrations. Low DO concentrations $\left(<2 \mathrm{mg} \mathrm{L}^{-1}\right)$ and high ferrous concentrations found in $55 \%$ of the bores indicated that redox conditions are suitable for nitrate attenuation by either denitrification or dissimilatory nitrate reduction to ammonium. The reducing environment may be associated with the high DOC concentrations (up to $82 \mathrm{mg} \mathrm{C} \mathrm{L}^{-1}$ ) found in these groundwaters. Furthermore, the high levels of ferrous iron found, combined with the widespread geographical distribution of DOC, indicated that these areas have a high potential for sustaining geochemical processes that reduce nitrate levels. Distribution of geochemical indicators also suggested that shallower depths $(<15 \mathrm{~m})$ of groundwater systems have more potential for nitrate reduction than deeper depths. The map identifying the areas in the lower Burdekin with the most potential for denitrification is a valuable first step in helping to understand and manage the fate of nitrate entering groundwater (Thayalakumaran et al., 2008).

In Jordan, water, rather than land is the determining factor for increasing the size and the productivity of the irrigated areas. Traditional surface irrigation is the general practice and the farmers themselves have been managing their water in terms of distribution and scheduling. The major developments in irrigation started in the 1950s were aimed at integrated rural development of the Jordan Valley which would utilize Jordan's share of the water resources of the Jordan River System. Currently, irrigation is practiced in two main areas: the Jordan rift valley (JRV) and the Upland. Macronutrients (N, P, and K) and some heavy metals $(\mathrm{Cd}, \mathrm{Cr}, \mathrm{Cu}, \mathrm{Fe}, \mathrm{Mn}, \mathrm{Ni}, \mathrm{Pb}$, and $\mathrm{Zn}$ ) have been studied in soil profiles irrigated by different water qualities. Two agricultural areas were selected for this purpose: one irrigated with fresh water from the Yarmouk River and the other irrigated with treated wastewater from the King Talal Dam. Results showed that the concentrations of heavy metals in the soils from the selected farms are within accepted values. It was also found that there was an increase in the concentration of nitrogen, potassium, and phosphate in most of the selected farms. An awareness program is highly recommended in order to draw the attention of farmers to this serious problem (Al-Zu'bi, 2007).

Waterlogged soils are submitted to temporal variations of aeration and aerobic-anaerobic conditions which influence redox conditions, and thus, element mobility. Cultivated paddy soils that are an accurate redox-dynamic environment can be found in Camargue (Rhône deltaic plain, southeastern France). In order to monitor fast physical and chemical variations in the waterlogged soil, a multiparametric probe was chosen to obtain continuous and in situ data. It can be shown that (i) redox potential (Eh) variations happen at almost constant $\mathrm{pH}$ during Mediterranean storms in non-irrigated seasons, and induce sharp variations of $\mathrm{Fe}$ (II) and $\mathrm{Mn}$ concentrations, and (ii) the soil is saturated with water under anaerobic conditions during long periods where sharp $\mathrm{pH}$ fluctuations controlled by $\mathrm{CO}_{2}$ pressure evolution affect redox processes. During irrigation periods, $\mathrm{Fe}$ and $\mathrm{Mn}$ precipitate as oxides or co-precipitate with $\mathrm{Al}, \mathrm{Mg}$, and $\mathrm{Si}$ at depth. However, these neoformed phases can be dissolved when irrigation stops. Understanding the reactions of the system under varying conditions is important in order to better assess its durability and anticipate the consequences of changes in soil use or agricultural practices (Cary and Trolard, 2008).

\section{MODELING AND CASE STUDIES}

A variety of analytical and numerical models have been developed during the past decades to predict water and solute transfer processes between the soil surface and the groundwater table.

One of the most popular models is HYDRUS (1-D, 2-D, and 3-D), originally developed and released by the U.S. Salinity Laboratory, Riverside, California, USA (Šimůnek et al., 1999). It is a finite element model that solves Richard's equation for flow and the advectiondispersion equation for solute and heat transport. Sorption, decay, and chemical reactions are also included. Further information can be found on the website www.pcprogress.cz. A multiplicity of examples and applications can be found in the literature. Some examples and simulations connected to irrigation are given in the following references. Gonçalves et al. (2006) used HYDRUS-1D to analyze water flow and solute transport in three soil lysimeters $\left(1.2 \mathrm{~m}^{2} \times 1 \mathrm{~m}\right)$ irrigated during 
the summer months with different quality waters used to evaluate salinization and alkalization hazards. Wöhling et al. (2004) used HYDRUS-2D for modeling twodimensional infiltration of irrigation furrows. Gärdenäs et al. (2005) presented a two-dimensional modeling approach providing information to improve fertigation practices. The specific objective of this project was to assess the effect of fertigation strategy and soil type on nitrate leaching potential for four different microirrigation systems. They found that seasonal leaching was the highest for coarse-textured soils concluding that fertigation at the beginning of the irrigation cycle tended to increase seasonal nitrate leaching. In contrast, fertigation events at the end of the irrigation cycle reduced nitrate leaching potential. Similar investigations with the HYDRUS- 2D model were carried out by Hanson et al. (2006) and Ajdary et al. (2007).

Applicability of the Leaching Estimation and Chemistry Model (LEACHM) to describe potassium (K) leaching in a sandy soil was tested by Kolahchi and Jalali (2006). K movement was examined with leaching columns. The model was able to predict $\mathrm{K}$ retardation. Field experiments in the unsaturated zone of a sandy soil under citrus production were simulated with LEACHM by Paramasivam et al. (2002). Data showed that 21 to $36 \%$ of applied $\mathrm{N}$ fertilizer leached below the root zone while tree uptake accounted for 40 to $53 \%$. The study enhanced the understanding of $\mathrm{N}$ dynamics in sandy soils providing a better evaluation of $\mathrm{N}$ and irrigation management to improve uptake efficiency, reduce $\mathrm{N}$ losses, and minimize the risk of groundwater nitrate contamination from soils highly vulnerable to nutrient leaching.

Yang et al. (2007) used the nitrogen simulation model DRAINMOD-N to predict nitrate-N concentrations in surface runoff and drain outflows from subsurfacedrained farmlands in southern Ontario, Canada. Data were collected in a corn field from 16 conventional drainage and subirrigation plots in Woodslee, Ontario, from 1992 to 1994 . Observed and simulated nitrate- $\mathrm{N}$ concentrations in surface runoff and drain outflows were compared. Results showed that the DRAINMOD-N model can perform a satisfactory simulation of soil hydrology and nitrate-N losses in surface runoff under various water table management practices. However, a precise calculation of water table depth is an essential prerequisite for a model to obtain a proper prediction of nitrate- $\mathrm{N}$ movement.

In structured soils, macropores can contribute to rapid movement of water and solutes through the profile. Malone et al. (2001) evaluated this component with $30 \mathrm{x}$ $30 \times 30 \mathrm{~cm}$ soil blocks of undisturbed, no-till silt loam with natural macropores. Atrazine, alachlor, and bromide were surface-applied at three water contents (dry, intermediate, and wet), and one hour later, the blocks were subjected to a simulated rainfall of $30 \mathrm{~mm}$ for 0.5 hour. The percolate was collected and analyzed at the base of the blocks. After percolation ceased, the soil was sectioned and analyzed to determine chemical distribution. The Root Zone Water Quality Model (RZWQM) was used for simulation. The simulated values were within a factor 2 range of the mean observed value. Model modifications could improve simulations, such as incorporating dynamic effective macroporosity (effective macroporosity increases as rainfall increases) and chemical kinetics in macropores.

Rinaldi et al. (2007), in a case study from southern Italy, compared nitrogen and irrigation strategies in tomato with the CROPGRO model. The CROPGRO simulation model is part of the Decision Support System for Agrotechnology Transfer (DSSAT) software. The model was calibrated to process tomato with a 2002 data set and validated with three independent data sets with acceptable results. Subsequently, the model was combined with 53 years of local historical weather data and used as a research tool to evaluate the benefits, risks, and costs of 23 different interactive irrigation and/or $\mathrm{N}$-management scenarios. A simple economic analysis was used to estimate expected net return for each management scenario, including tomato marketable yield and price, irrigation and nitrogen cost, and other fixed production costs. It was found that frequent irrigation applications with a low amount (3-day interval and $15 \mathrm{~mm}$ application ) combined with low $\mathrm{N}$ rates reduced crop stress and represented the best scenario from both a productive and environmental point of view (low N leaching).

Popova and Kercheva (2004) also used DSSAT software, in this case the CERES-maize model, to evaluate the long-term impact of irrigation scheduling and rates, timing of fertilization on water stress indicators, nitrogen uptake, and leaching under maize in Chromic Luvisol, Sofia region, Bulgaria. Adjusted and modified CERES-maize was run with different irrigation and fertilization scenarios, and 30-year weather data. Scenario analyses proved that grain yield and N-uptake were severely affected on drylands under the study conditions. Drought indicators showed that irrigation was required in $70 \%$ of the years. An integrated management strategy of $\mathrm{N}$-application that was timed to coincide with the period of maximum crop uptake and irrigation scheduled at $85 \%$ of field capacity reduced available $\mathrm{N}$ for leaching in the risky years. A drainage control scenario, developed for $75-80 \%$ of the required irrigation depth and predominantly satisfying the most sensitive phases of maize development, saved up to $95 \mathrm{~mm} \mathrm{yr}^{-1}$ of water and reduced drainage by $30-40 \%$ in medium wet to wet fallow states.

The Agricultural Production Systems Simulator - Soil Water Infiltration and Movement (APSIM-SWIM) was 
used by Stewart et al. (2006) to estimate deep drainage and nitrate leaching from the root zone under sugarcane (Saccharum officinarum) at the Burdekin Delta in North Queensland, Australia located on a dry tropical coastal strip and one of Australia's premier sugar-producing districts with approximately 40000 ha of land under sugarcane. Collection of data related to drainage and nitrate leaching over two cropping seasons at a specific field site and their use in the calibration and application of the model was described. Model simulations indicated that the amount of drainage and nitrate leached over a cropping season compared favorably to that derived from inferred drainage and observed soil-water nitrate concentrations. Subsequent investigation of fertilizer management options using the model identified the timing and amount of both irrigation and fertilizer application as key parameters over which management control might be utilized to minimize deep drainage and flux of nitrate to groundwater.

The objective of the study by Chung et al. (2003) was to develop a model of groundwater loading effects of agricultural management systems in paddy fields. They modified the Groundwater Loading Effects of Agricultural Management Systems (GLEAMS) model which is used for uplands. The application of GLEAMS in paddy fields (GLEAMS-PADDY model) is made up of hydrological and chemical sub-models. Field experiments were carried out in the Soro region, Chungbuk Province, South Korea from May 1999 to September 2000. Field data included the amount of rainfall, irrigation water input, drainage water output, and percolation. Concentrations were analyzed of total nitrogen (T-N) and total phosphorus (TP) in irrigation water, rainwater, pounded water, surface drainage water, and percolated water. Comparisons of observed and predicted model water balance components, nutrient concentrations, and loading rates concurred reasonably. Hence, the use of the GLEAMS-PADDY model can reduce surface water pollution from paddy field drainage water.

The determination of nitrate distribution through modeling represents a highly complex nonlinear problem that includes adsorption, transformation, convection, and dispersion. For this reason Li et al. (2004b) proposed an alternative methodology which combines artificial neural networks (ANN) and laboratory experiments. Seventeen column experiments with varying discharge rates and varying input fertilizer concentrations $\left(\mathrm{NH}_{4}-\mathrm{NO}_{3}\right)$ were conducted to provide a database to establish ANN architecture. A total of 298 vectors were used to train the ANN model and 212 independent vectors were used to test it. Results of the test showed a good correspondence between the model estimated nitrate concentration in the soil and laboratory measured nitrate values. These results showed that the optimized ANN models are reasonably accurate and can provide an easy and efficient means of estimating nitrate distribution in the soil under fertigation through drip irrigation systems.

Contamination of groundwater by agrochemicals is now widely recognized as an extremely important environmental problem. Modern agricultural practices involve the combined use of irrigation with the application of large amounts of agrochemicals to maximize crop yield. Agricultural activities might generate soil, surface water, and groundwater contamination problems and leaching of pesticides due to flood irrigation and natural runoff. Modeling of the transport and fate of pesticides, such as simazine, can help us to understand the longterm potential risk to the subsurface environment. A comparative study has been reported via the use of three different pesticide transport simulation models and the applicability of those models in determining groundwater vulnerability to pesticide contamination in a citrus orchard located in the Lower Rio Grande Valley (USA). The three models used in the study are the pesticide root zone model-3 (PRZM-3), pesticide analytical model (PESTAN), and integrated pesticide transport modeling (IPTM). Concentration values obtained from all three models agree and show a decreasing trend from the surface through the vadose zone. The problem is how to use this information and, more specifically, how to combine the testimony of a number of experts into a single useful judgment. With the aid of the fuzzy multiattribute decision making method, PRZM-3 is deemed to be the most promising for such precision farming applications (Chang et al., 2008)

\section{CONCLUSIONS}

Analysis of the scientific articles reviewed shows that the information related to the impact of irrigation practices on soil and water quality in Latin America is scarce and fragmentary. Studies refer mainly to waterlogging and salinization. As regards agrochemicals, fertilizers have been taken into account by considering nitrate leaching. The impact of micropollutants such as pesticides and heavy metals on water and soil quality were studied through modeling. Research on emerging micropollutants, such as pharmaceutical compounds, has increased in the last few years.

The use of wastewater, with or without treatment, is increasing in arid and semi-arid regions because it is a valuable resource. The environmental effects of its use in irrigation have to be taken into account. Knowledge is needed about appropriate technologies for the use, treatment, and reuse of wastewater. Risk analysis based on suitable indicators must be considered. 
The literature reviewed for countries other than Latin American and Caribbean countries also shows fragmentary information. However, concern about the importance of studying the environmental impact of irrigation practices on water and soil quality is clearly established. Several studies on this subject have been reported in different countries such as Australia, China, India, and the USA among others.

Analysis of the environmental effects of irrigated agriculture needs to take into account the dynamic processes of all the interactions in the watershed and recognize the driving forces (population growth, climate change, land use, urbanization, and market impacts).

Soil and water monitoring is required. Research institutes should construct the framework for monitoring with the long-term support of governments.

An interdisciplinary approach is required to understand the processes in the watershed by taking into consideration water availability, water demand, and water quality at the basin scale, and taking into account the demands of other users. The establishment of an appropriate baseline, as well as the design of future scenarios is important.

\section{RESUMEN}

Efectos ambientales del riego en regiones áridas y semi-áridas. En este trabajo se presenta una revisión del estado del arte relativo a los efectos ambientales de la agricultura bajo riego en la calidad del agua y de los suelos en regiones semiáridas y áridas de América Latina a escala de campo. La información relevada es escasa y fragmentaria. Ejemplos en áreas seleccionadas de otras regiones del mundo muestran claramente la importancia del estudio del impacto ambiental de las prácticas de riego en la calidad de agua y del suelo. La mayor parte de los estudios se refieren a anegamiento y salinización de suelos. En relación a los agroquímicos, los fertilizantes han recibido mayor atención, en particular considerando la lixiviación de nitratos. El impacto de los microcontaminantes, como los pesticidas o los metales pesados, se ha estudiado mayormente a través de la aplicación de modelos. Los compuestos farmacéuticos surgen como contaminantes cuando las aguas servidas se usan para riego sin tratamiento previo, y han comenzado a ser objeto de estudio. Es evidente la necesidad de profundizar los conocimientos en relación a las tecnologías apropiadas de uso, tratamiento y reutilización de aguas servidas, pues constituyen un valioso recurso en regiones semiáridas y áridas.

Palabras clave: riego, calidad de agua, calidad de suelo, agroquímicos, microcontaminantes.

\section{LITERATURE CITED}

Ajdary, K., D.K. Singh,A.K. Singh, and M. Khanna. 2007. Modelling of nitrogen leaching from experimental onion field under drip fertigation. Agric. Water Manage. 89:15-28.

Al-Zu'bi, Y. 2007. Effect of irrigation water on agriculture soil in Jordan valley: An example from arid area conditions. J. Arid Environ. 70:63-79.

Amado, T.J.C., P.C. Conceicao, C. Bayer, and F. Elts. 2007. Soil quality devaluated by "Soil Quality Kit" in two long-term soil management experiments in Rio Grande do Sul State, Brazil. Revista Brasileira de Ciencia do Solo 31:109-121.

Andrade, J.A.S., Ênio F. de F. Silva, E.A. Bastos, F. de B. Melo, and C.M. Leal. 2006. Use and quality of groundwater for irrigation in semi-arid region of the Piauí State, Brazil. R. Bras. Eng. Agric. Ambiental 10:873-880.

Aparicio, V., J.L. Costa, and M. Zamora. 2008. Nitrate leaching assessment in a long-term experiment under supplementary irrigation in humid Argentina. Agric. Water Manage. 95:1361-1372.

Arumi, J.L., R.A. Oyarzún, and M. Sandoval. 2005. A discussion about natural protection again groundwater pollution by nitrates in the Central Valley of Chile. Hydrol. Sci. J. 50:331-340.

Ayars, J.E., E.W. Christen, and J.W. Hornbuckle. 2006. Controlled drainage for improved water management in arid regions irrigated agriculture. Agric. Water Manage. 86:128-139.

Barrios, E., R.J. Delve, C. Bekunda, J. Mowo, J. Agunda, J. Ramisch, et al. 2006. Indicators of soil quality: A South-South development of a methodological guide for linking local and technical knowledge. Geoderma 135:248-259.

Benyamini, Y., V. Mirlas, S. Marish, M. Gottesman, E. Fizik, and M. Agassi. 2005. A survey of soil salinity and groundwater level control systems in irrigated fields in the Jezre'el Valley, Israel. Agric. Water Manage. 76:181-194.

Cary, L., and F. Trolard. 2008. Metal mobility in the groundwater of a paddy field in Camargue (South eastern France). J. Geochem. Explor. 96:132-143.

Chang, Ni-Bin, K.R. Srilakshmi, and G. Parvathinathan. 2008. Comparison of models of simazine transport and fate in the subsurface environment in a citrus farm. J. Environ. Manage. 86:27-43.

Chefetz, B., T. Mualem, and J. Ben-Ari. 2008. Sorption and mobility of pharmaceutical compounds in soil irrigated with reclaimed wastewater. Chemosphere 73:1335-1343. 
Chowdary, V.M., N.H. Rao, and P.B.S. Sarma. 2005. Decision support framework for assessment of non-point-source pollution of groundwater in large irrigation projects. Agric. Water Manage. 75:194-225.

Chung, S.-O., H.-S. Kim, and J.S. Kim. 2003. Model development for nutrient loading from paddy rice fields. Agric. Water Manage. 62:1-17.

Costa, J.L., H. Massone, D. Martinez, E.E. Suero, C.M. Vidal, and F. Bedmar. 2002. Nitrate contamination of a rural aquifer and accumulation in the unsaturated zone. Agric. Water Manage. 57:33-47.

Costa Paraíba, L., A.L. Cerdeira, E. Fraga da Silva, J. Souza Martins, and H.L. da Costa Coutinho. 2003. Evaluation of soil temperature effect on herbicide leaching potential into groundwater in the Brazilian Cerrado. Chemosphere 53:1087-1095.

Cutz-Pool, L., J.G. Palacios-Vargas, G. Castaño Meneses, and N. García Calderón. 2007. Edaphic Collembola from two agroecosystems with contrasting irrigation type in Hidalgo State, Mexico. Appl. Soil Ecol. 36:46-52.

Dogliotti, S., M.K. van Ittersum, and W.A.H. Rossing. 2006. Influence of farm resource endowment on possibilities for sustainable development: A case study for vegetable farms in South Uruguay. J. Environ. Manage. 78:305-315.

Ericksen, P.J., and M. Ardón. 2003. Similarities and differences between farmer and scientist views on soil quality issues in central Honduras. Geoderma 111:233-248.

FAO. 2000. Irrigation in Latin America and Caribbean in Figures. 348 p. Food and Agriculture Organization of the United Nations (FAO), Rome, Italy. Available at http://www.fao.org (accessed 29 October 2009).

Fiege, M. 1999. Irrigated Eden: The making of an agricultural landscape in the American West. 323 p. University of Washington Press, Seattle, Washington, USA.

Gallegos, E., A. Warren, E. Robles, E. Campoy, A. Calderón, M. Sainz, et al. 1999. The effects of wastewater irrigation on groundwater quality in Mexico. Water Sci. Technol. 40(2):45-52.

Gärdenäs, A.I., J.W. Hopmans, B.R. Hanson, and J. Šimůnek. 2005. Two-dimensional modeling of nitrate leaching for various fertigation scenarios under microirrigation. Agric. Water Manage. 74:219-242.

Geerts, S., D. Raes, M. Garcia, O. Condori, J. Mamani, R. Miranda, et al. 2008. Could deficit irrigation be a sustainable practice for quinoa (Chenopodium quinoa Willd.) in the Southern Bolivian Altiplano? Agric. Water Manage. 95:909-917.

Ghiberto, P.J., M.A. Pilatti, S. Imhoff, and J.A. de Orellana. 2007. Hydraulic conductivity of Molisolls irrigated with sodic-bicarbonated waters in Santa $\mathrm{Fe}$ (Argentine). Agric. Water Manage. 88:192-200.
Gonçalves, M.C., J. Šimůnek, T.B. Ramos, J.C. Martins, M.J. Neves, and F.P. Pires. 2006. Multicomponent solute transport in soil lysimeters irrigated with waters of different quality. Water Resour. Res. 42(8):W08401. doi:10.1029/2005WR004802.

González, M.L., D.A. López, and C. Gatica. 2004. Effect of soil-use on deep groundwater quality in Southern Chile. Int. J. Environ. Pollut. 21:240-252.

González Vázquez, J.C., J.A. Grande, F.J. Barragán, J.A. Ocaña, and M.L.de la Torre.2005.Nitrate accumulation and other components of the groundwater in relation to cropping system in an aquifer in Southwestern Spain. Water Resour. Manage. 19:1-22.

Guo, H., G. Li, D. Zhang, X. Zhang, and Ch. Lu. 2006. Effects of water table and fertilization management on nitrogen loading to groundwater. Agric. Water Manage. 82:86-98

Hanson, B.R., J. Šimůnek, and J.W. Hopmans. 2006. Evaluation of urea-ammonium-nitrate fertigation with drip irrigation using numerical modeling. Agric. Water Manage. 86:102-113.

Herpin, U., T.V. Gloaguen, A. Ferreira da Fonseca, L.R. Montes, F. Campos Mendonça, R. Passos Piveli, et al. 2007. Chemical effects on the soil-plant system in a secondary treated wastewater irrigated coffee plantation. A pilot field study in Brazil. Agric. Water Manage. 89:105-115.

Herre, A., C. Siebe, and M. Kaupenjohann. 2004. Effect of irrigation water quality on organic matter, $\mathrm{Cd}$ and $\mathrm{Cu}$ mobility in soils of central Mexico. Water Sci. Technol. 50:277-284.

Hornbuckle, J.W., E.W. Christen, and R.D. Faulkner. 2007. Evaluating a multi-level subsurface drainage system for improved drainage water quality. Agric. Water Manage. 89:208-216.

Inter-American Development Bank. 2000. Irrigation and water resources in Latin America and the Caribbean: challenges and strategies. 92 p. Inter-American Development Bank, Environment and Production Technology Division, Washington D.C., USA.

Khan, S., R. Tariq, C. Yuanlai, and J. Blackwell. 2006. Can irrigation be sustainable? Agric. Water Manage. 80:87-99.

Kolahchi, Z., and M. Jalali. 2006. Simulating leaching of potassium in a sandy soil using simple and complex models. Agric. Water Manage. 85:85-94.

Li, Z.Z., W.D. Li, and W.L. Li. 2004a. Dry-period irrigation and fertilizer application affect water use and yield of spring wheat in semi-arid regions. Agric. Water Manage. 65:133-143.

Li, J., R.E. Yoder, L.O. Odhiambo, and J. Zhang. 2004b. Simulation of nitrate distribution under drip irrigation using artificial neural networks. Irrig. Sci. 23:29-37. 
Maarten, K., A. Jaeger, A. Bronstert, and A. Güntner. 2006. Integrated modeling of climate, water, soil, agricultural and socio-economic processes: A general introduction of the methodology and some exemplary results from the semi-arid north-east of Brazil. J. Hydrol. 328:417-431.

Malone, R.W., M.J. Shipitalo, L. Ma, L.R. Ahuja, and K.W. Rojas. 2001. Macropore component assessment of the Root Zone Water Quality Model (RZWQM) using no-till soil blocks. Trans. ASAE 44:843-852.

Mantel, S., V.W.P. van Engelen, J.H. Molfino, and J. Resink. 2000. Exploring biophysical potential and sustainability of wheat cultivation in Uruguay at the national level. Soil Use Manage. 16:270-278.

Noellemeyer, E., A.R. Quiroga, and D. Estelrich. 2006. Soil quality in three range soils of the semi-arid Pampa of Argentina. J. Arid Environ. 65:142-155.

Oad, R., and R. Kullman. 2006. Managing irrigation for better river ecosystems - A case study of the Middle Rio Grande. J. Irrig. Drain. E-ASCE 132:579-586.

Ojeda-Bustamante, W., J.M. González-Camacho, E. Sifuentes-Ibarra, E. Isidro, and L. Rendón-Pimentel. 2007. Using spatial information systems to improve water management in Mexico. Agric. Water Manage. 89:81-88.

Ortega-Larrocea, M.P., C. Siebe, A. Estrada, and R. Webster. 2007. Mycorrhizal inoculum potential of arbuscular mycorrhizal fungi in soils irrigated with wastewater for various lengths of time, as affected by heavy metals and available P. Appl. Soil Ecol. 37:129138.

Oyarzun, R., J. Arumi, and M. Marino. 2007. Sensitivity analysis and field testing of the RISK-N model in the Central Valley of Chile. Agric. Water Manage. $87: 251-260$.

Paramasivam, S., A.K. Alva, A. Fares, and K.S. Sajwan. 2002. Vadose zone processes and chemical transport fate of nitrate and bromide in an unsaturated zone of a sandy soil under citrus production. J. Environ. Qual. 31:671-681.

Popova, Z., and M. Kercheva. 2004. Integrated strategies for maize irrigation and fertilization under water scarcity and environmental pressure in Bulgaria. Irrig. Drain. 53:105-113.

Qadir, M., B.R. Sharma, A. Bruggeman, R. ChoukrAllah, and F. Karajeh. 2007. Non-conventional water resources and opportunities for water augmentation to achieve food security in water scarce countries. Agric. Water Manage. 87:2-22.

Reichenberger, S., W. Amelung, V. Laabs, A. Pinto, K.U. Totsche, and W. Zech. 2002. Pesticide displacement along preferential flow pathways in a Brazilian Oxisol. Geoderma 110:63-86.
Ribbe, L., P. Delgado, E. Salgado, and W.-A. Flügel. 2008. Nitrate pollution of surface water induced by agricultural non-point pollution in the Pocochay watershed, Chile. Desalination 226:13-20.

Rinaldi, M., D. Ventrella, and C. Gagliano. 2007. Comparison of nitrogen and irrigation strategies in tomato using CROPGRO model. A case study from Southern Italy. Agric. Water Manage. 87:91-105.

Ruda, E., A. Mongiello, A. Acosta, L. Contini, y E. Ocampo. 2005. Calidad del agua subterránea con fines de riego suplementario en Argiudoles del Centro de Santa Fe, Argentina. Agric. Téc. (Chile) 65:411420.

Ryan, M.C., G.R. Graham, and D.L. Rudolph. 2001. Contrasting nitrate adsorption in Andisols of two coffee plantations in Costa Rica. J. Environ. Qual. 30:1848-1852.

Ryder, R. 2003. Local soil knowledge and site suitability evaluation in the Dominican Republic. Geoderma 111:289-305.

Senna de Oliveira, T., L.M. de Costa, and C.E. Schaefer. 2005. Water-dispersible clay after wetting and drying cycles in four Brazilian oxisols. Soil Tillage Res. 83:260-269.

Shigaki, F.S., and L.A. Prochnow. 2006. Animal-based agriculture, phosphorus management and water quality in Brazil: options for the future. Sci. Agric. (Piracicaba, Braz.) 63:313-313.

Siemens, J., G. Huscheka, C. Siebe, and M. Kaupenjohanna. 2008. Concentrations and mobility of human pharmaceuticals in the world's largest wastewater irrigation system, Mexico City-Mezquital Valley. Water Res. 42:2124-2134.

Šimůnek, J., M. Sejna, and M.Th. van Genuchten. 1999. The HYDRUS-2D software for simulating the two-dimensional movement of water, heat, and multiple solutes in variably-saturated media. 251 p. International Ground Water Modeling Center, Colorado School of Mines, Golden, Colorado, USA.

Smedema, L.K., and K. Shiati. 2002. Irrigation and salinity: a perspective review of the salinity hazards of irrigation development in the arid zone. Irrig. Drain. Syst. 16:161-174.

Stewart, L.K., P.B. Charlesworth, K.L. Bristowa, and P.J. Thorburn. 2006. Estimating deep drainage and nitrate leaching from the root zone under sugarcane using APSIM-SWIM. Agric. Water Manage. 81:315-334.

Szynkiewicz,A., M.R. Medina, M. Modelska, R. Monreal, and L.M. Pratt. 2008. Sulfur isotopic study of sulfate in the aquifer of Costa de Hermosillo (Sonora, Mexico) in relation to upward intrusion of saline groundwater, irrigation pumping and land cultivation. Appl. Geochem. 23:2539-2558. 
Tarawally, M.A., H. Medina, M.E. Frómeta, and C.A. Itza. 2004. Field compaction at different soil-water status: effects on pore size distribution and soil water characteristics of a Rhodic Ferralsol in Western Cuba. Soil Tillage Res. 76:95-103.

Thayalakumaran, T., K.L. Bristowa, P.B. Charlesworth, and T. Fass. 2008. Geochemical conditions in groundwater systems: Implications for the attenuation of agricultural nitrate. Agric. Water Manage. 95:103115.

Trujillo-Tapia N., C. Cruz Mondragón, M.S. VásquezMurrieta, O. Van Cleemput, and L. Dendooven. 2008. Inorganic $\mathrm{N}$ dynamics and $\mathrm{N}_{2} \mathrm{O}$ production from tannery effluents irrigated soil under different water regimes and fertilizer application rates: A laboratory study. Appl. Soil Ecol. 38:279-288.

Vázquez, M., G. Millán, y P. Gelati. 2006. Sustentabilidad del riego complementario en suelos Udipsament Típico y Hapludol Entico de Argentina. R. Bras. Eng. Agríc. Ambiental 10:593-603.

Vieira de Azevedo, P., J. Monteiro Soares, V. de Paulo Rodrigues da Silva, B. Barbosa da Silva, and T. Nascimento. 2008. Evapotranspiration of 'Superior' grapevines under intermittent irrigation. Agric. Water Manage. 95:301-308.
Wöhling, Th., G.H. Schmitz, and J.-C. Mailhol. 2004. Modeling two-dimensional infiltration from irrigation furrows. J. Irrig. Drain. Eng. 130:296-303.

World Bank. 2000. Argentina water resources management. Policy Issues and Notes. 190 p. World Bank, Washington, DC, USA. Available at http:// www.worldbank.org (accessed 3 November 2009).

World Bank. 2007. Changing farm types and irrigation as an adaptation to climate change in Latin American agriculture. World Bank Policy Research Working Paper 4161. 41 p. World Bank, Washington, DC, United States. Available at http://www.worldbank.org (accessed 3 November 2009).

Yahdjian, L., and O.E. Sala. 2008. Do litter decomposition and nitrogen mineralization show the same trend in the response to dry and wet years in the Patagonian steppe? J. Arid Environ. 72:687-695.

Yang, C.C., S.O. Prasher, S. Wang, C.S. Tan, C. Drury, and R.M. Patel. 2007. Simulation of nitrate-N movement in Southern Ontario, Canada with DRAINMOD-N. Agric. Water Manage. 87:299-306.

Zhang, M., Z. Hea, D.V. Calvert, and P.J. Stoffella. 2004. Spatial and temporal variations of water quality in drainage ditches within vegetable farms and citrus groves. Agric. Water Manage. 65:39-57. 